\title{
MOLECULAR DOCKING OF SARS-COV-2-NUCLEOCAPSID PROTEIN WITH ANGIOTENSIN-CONVERTING ENZYME II
}

\author{
Ali A. Dawood', Mahmood AA. Altobje ${ }^{2}$,Zeyad T. Al-Rrassam ${ }^{3}$ \\ ${ }^{1}$ Department of Anatomy, College of Medicine, University of Mosul, Mosul, Iraq \\ ${ }^{2}$ Department of Biology, College of Science, University of Mosul, Mosul, Iraq \\ ${ }^{3}$ Department of Biophysics, College of Science, University of Mosul, Mosul, Iraq \\ e-mail:aad@uomosul.edu.iq
}

\begin{abstract}
SARS-CoV-2 remains life-threatening human pathogen witnessed in the present world. Purpose. The key objective of this research was to incorporate a bioinformatics technique to forecast the molecular docking of the ACE2-associated SARS-CoVs nucleocapsid protein. Methods. Different bioinformatics tools were used in this study in order to compare the chemical structures with their biological behaviour at the levels of atoms and the ligand-binding affinity. This research sought to investigate new data analysis. Results. It was computed the basic $2 D$ structure that occurs in all models, requiring ion ligand binding sites to be predicted. The highlights of the analysis and the associated characteristics are largely responsible for nucleocapsid protein and ACE2 receptor that can be further changed for improved binding and selectivity. Conclusions. The precise functional importance of protein-protein docking cannot be established. But the detection of molecular docking can aid in self-association proteins in our summary, serving as a regulatory switch for the protein's localization.
\end{abstract}

Keywords: COVID-19, SARS-CoV-2, angiotensin-converting enzyme II (ACE2), nucleocapsid, molecular docking, receptor-binding domain (RBD) protein, RMSD.

During the various stages of the SARS-CoV-2 pandemic, improvements in risk, propaganda and potential interventions have been defined. This is an opportunity to gain insight into the behaviours and the aspirations of the world. In most cases, the bulk of coronaviruses originate from zoonotic dissemination. However, there is still no confirmation that SARS-CoV-2 was born from the marine industry. In the majority of data reports, SARS-CoV-2 could be less virulent as SARS-CoV-2003 and MERS-CoV-2018. SARS$\mathrm{CoV}-2$ in the Coronaviridae family is related to $\beta$-coronavirus and split virus of RNA (sub-family Orthocoronavirinae) [1-3].

Four fundamental structural proteins are encoded by the positive-sense viral RNA genome: spike glycoprotein, envelope protein, membrane protein, and nucleocapsid protein (NP) [4]. Three distinct preserved domains, two structural and independently folded structural regions, make up the NP. The N-terminal domains NTD1 and NTD3 are separated by the central region (RNA-binding domain/2) and the C-terminal domain CTD3 [5]. The NP plays a pivotal role in viral pathogenesis, causes cell cycle deregulation, inhibits type 1 interferon synthesis and improves viral RNA transcription efficiency and viral replication [6].
The synthesis of viral RNA and proteins is also regulated by NP. Moreover, by inducing humoral and cellular immunity, NP serves as a potent immunogen. It was found that in both SARS-CoV and MERS-CoV, NP is considered as a possible vaccine candidate [7].

In the replication cycle, the association between the viral protein and the host cell membrane receptor is a key step. Therefore this process relies on the efficacy of viral infection. The coronavirus binds the human host cell to the angiotensinconverting enzyme II (ACE2) through the binding of the receptor-binding domain (RBD) protein $[8,9]$. Currently unclear is the molecular mechanism of this RBD-ACE2 attachment [10]. It exists in the lower respiratory tract cells and governs transmission between animals and between humans. Other cellular receptors, such as CD209L, DC-SIGN, and C-type lectin, play a secondary role in viral attachment to the host cell membrane. Different biochemical variables are correlated with protein-protein relationships. The structure of protein residues and the form of chemical interactions occurring between the ligand and the receptor $[11,12]$ define these influences. Thus the presence of residues that create an interaction that is energetically preferred can drive binding kinetics 
and eventually contribute to the event of fusion.

One research has found that NP has a role in viral pathogenesis as monoclonal anti-N antibodies that sustain fatal infection in mice. Our previous study conducted several immunoinformatics such as CTLPred, NetCTL- NetMHC, BepiPred 2.0, and $\mathrm{ABCPred}$ to cytotoxic T-cell (CTL) and B-cell epitopes inside nucleocapsid phosphoprotein peptides [13].

On this basis, the objective of our research was to forecast and analyse the energy profile of the relationship between the SARS-CoV-2 NP and the ACE2 human cell receptor. The mathematical methodology used in this study is to approximate the molecular descriptors and the relationship between descriptors with binding affinity and selectivity using different bioinformatics tools. For viral nucleocapsid protein and ACE2 receptor, research highlights and association characteristics are primarily responsible for further improvement for enhanced binding and selectivity.

\section{Materials and methods}

Sequence comparison. In the current study, experimental binding affinity and selectivity data were conducted to determine the critical structural characteristics needed for binding affinity and to explore the structural criteria available for protein docking. SARS-CoV-2 (QJR91601.1), Bat CoVCp/Yunnan2011 (AGC74175.1), Bat SARSCoV HKU3-2 (AAZ41337.1), SARS CoV-TJF (AAT76155.1) and BtRl-Beta-CoV/SC20188, five amino acid sequences of NP linked to the coronavirus family have been selected from the NCBI FASTA format (QDF43818.1). Using the T-COFFEE server, multiple sequence alignment was achieved and checked by the CLUSTA-W tool and confirmed with MAFFT 7 [13].

Protein-protein interaction. Angiotensinconverting enzyme II precursor ACE2 Homo sapiens (NP 001358344.1) was blasted for protein association interaction inside the UniPort alignment server (https:/www.uniprot.org/align/) in addition to five amino acid sequences alignment of NPs and compared to the CLUSTAL-OMEGA tool in EMBL-EBI. Using MAFFT Version 7 (https:/mafft.cbrc.jp/alignment/software/tips.html), the phylogenetic tree was extracted and confirmed using the ViPR server (https://www.viprbrc.org/ brc/home.spg?decorator=vipr).

Predication ion ligand binding sites. Ion ligand binding site residues were removed from the IonCom server in Zhang lab (https:/zhanglab. ccmb.med.umich.edu/IonCom/) according to the build-up of the 2D structure of amino acid sequences: complete sequence of SARS-CoV-2 NP (QJR91601.1), RNA binding domain SARS-CoV NP (2OFZ) and ACE22 NP (2OFZ) (1R42).

Protein modelling. The SARS-CoV-2 NP Homology Structural Simulation was built based on the SWISS-MODEL server models and DeepView/ Swiss-PdbViewer 4.01 program. Several models were obtained and the higher sequence similarity measured the consistency of each structure. To optimize the protein similarity, we selected the crystal structure of SARS-CoVs NP in protein bank (PDB). The best model was obtained for SARS-CoV-2 NP for predicting the 3D structure. The projected models were subject to further optimization of the protein structure. The described MD simulations were used with NAMD 2.12 and Gasteiger charges. The lowest energy frame of the MD imitation was performed by the obtained structures. With the PROCHECK programs in PDBsum, the consistency of the models was created.

Molecular docking. For coronavirus NPs and ACE2 (1R42), the crystal structure was downloaded from the Protein Data Bank. It checked the homology models for CoV NPs. Then, using molecular docking, binding patterns, and affinity calculations were carried out for the proteinprotein interaction between the various domains of NPs and ACE2 receptors. In the present research, molecular docking analysis was applied to better explain the intermolecular interactions that take place between various sequences. Two steps were taken to generate the active docking process; first using Z-dock software, a blind docking between ligand NP and receptor ACE2 was performed. Then using PRODIGY software techniques, the resulting docking data was processed and analysed. (http://www.bonvinlab.org/software/) [14]. Finally, the data findings were clustered and evaluated in each complex, taking into account the binding energies and key interacting residues [15]. For all the receptor-ligand complexes, the ducker interaction energy parameter was tested and the top five scoring models were chosen as favourable for the binding.

Results. There were a high correlation and identification between SARS-CoV-2 NPs, BatCoV-HKU3-2, Bat-CoV-Cp/Yunnan, SARSCoV-TJA, and CoV BtR1-BetaCoV/SC2018 in the multiple sequence alignment (MSA) of the five series from various sources linked to the coronavirus family: $88.76 \%, 89.26 \%, 89.26 \%$, 
and $89.50 \%$, respectively. This discovery is not in accordance with our previous research showing that SARS-CoV-2 NP uses the T-COFFEE method to achieve $70 \%$ similarity related to Bat-SARS$\mathrm{CoV}$ due to different statistics on each server, which yield different results [16]. With five NP coronavirus genes, ACE2 was matched. The patterns of contact between the five viral NPs are very comparable. A low share resemblance between ACE2 and the NP sequences was observed as $16.96 \%, 16.86 \%, 17.11 \%, 17.11 \%$, and $17.16 \%$ (Fig. 1).
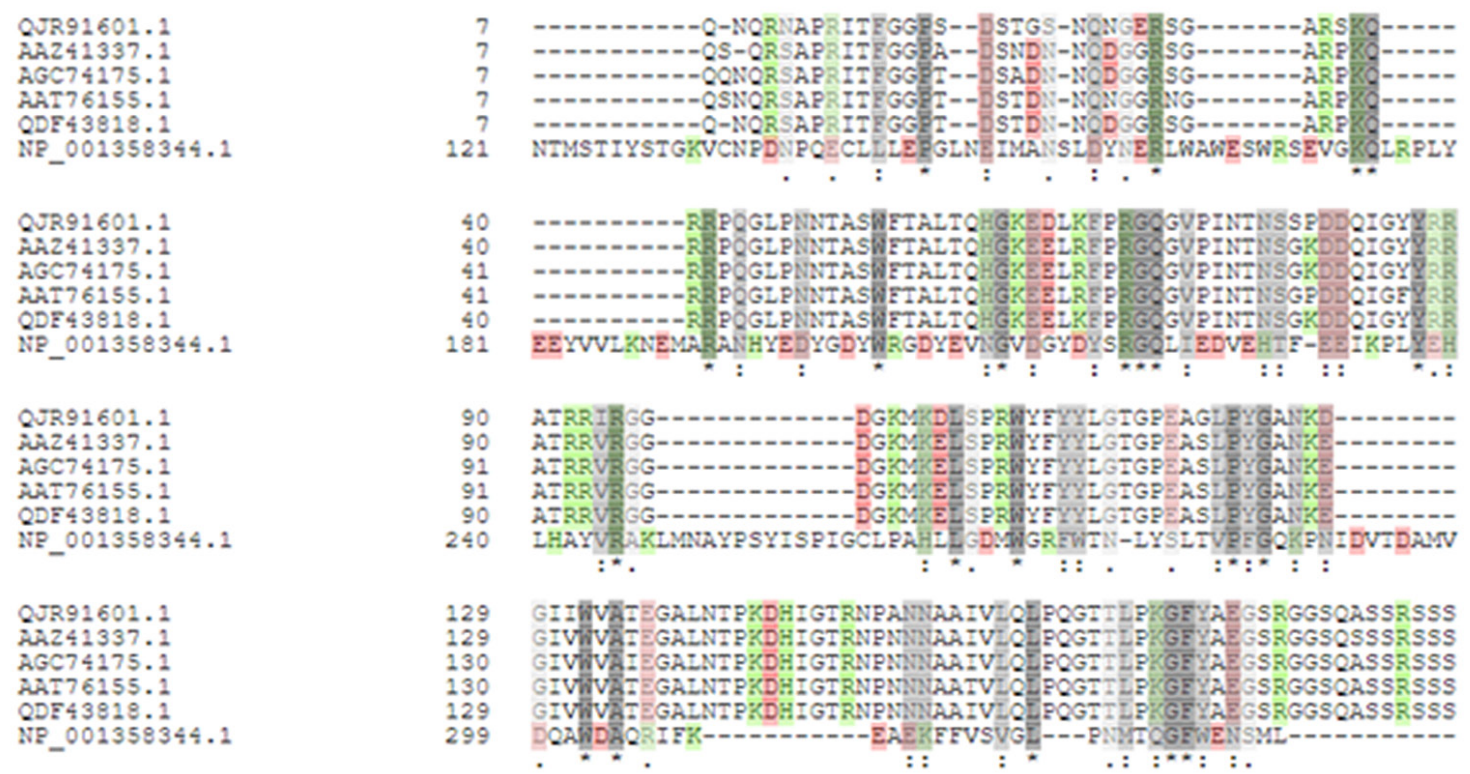

F i g. 1. Partial multiple sequence alignment (MSA) of five NP sequences and ACE2: dark grey lines show high match similarity and conserved sits; light grey line shows most conserved in high identity in sequences. Pink line shows positive correlations between sequences. $R$ in green line: exact similarity between sequences.

Arithmetic server research has been used to derive predictive ion ligand binding site residues for both NPs of coronaviruses and ACE2. We had several ion ligands predicted. For the full SARS-CoV-2 NP sequence, 18 residues of $\mathrm{Zn}$ (Zinc), 8 residues of $\mathrm{Cu}$ (Copper), 7 residues of $\mathrm{Ca}$ (Calcium), 5 residues of $\mathrm{Na}$ (Sodium), and 2 residues of K (Potassium) were reported in Table 1. The ion binding sites prediction for 2OFZ, were: $9 \mathrm{Zn}$ residues, $3 \mathrm{Fe}$ (iron) residues, $2 \mathrm{Mg}$ (magnesium) residues, $6 \mathrm{Mn}$ (manganese) residues, and $1 \mathrm{Na}$ residue (Table 1). ACE2 has detected 49 residues of $\mathrm{ZN}, 2$ residues of MG, and 6 residues of NA (Table 1). Loci of ions are presented on the prediction with $2 \mathrm{D}$ and $3 \mathrm{D}$ structure in Fig. 2.

\section{Structural analysis and molecular docking of} NP-ACE2 complexes

The SARS-CoV-2 NP crystal structures and Bat SARS-CoV homology models interacting with the putative binding domain site in human ACE2 were studied. According to the realm of engagement, the interaction pattern between them revealed different designs. RNA binding domain
X-ray crystal structure of SARS-CoV-2 NP, PDB (6VYO) resolution $1.70 \AA$ showed residues of ligand binding sites (Fig. 3, Table 2).

MSE on (201A, 203A, 202B and 204C), Gol (201B, 203C, 201D, and 202D), Zn ion on (206A, 203B, and 205C), and $\mathrm{Cl}$ ion metal are the following ligands: (202A, 205A, 201C, and 202C). The crystal structure of ACE2 in PDB (1R42) in $\mathrm{X}$-ray diffraction $2.2 \AA$ showed residues of ligand binding sites in Fig. 4, Table 2.

NAG (800A, 801A, and 802A), Zn ion metal $(804 \mathrm{~A})$, and $\mathrm{Cl}$ ion metal sites are ligand sites on ACE2 (803C). Figure 5 shows the docking and protein-protein interaction of NP 6VYO-ACE2. To detect probability docking models, we used Zdock server (http://zdock.umassmed.edu). We picked the top five probability models from Zdock that are forecast and evaluated and viewed with JavaScript.

The SARS-CoV NP dimerization domain (2GIB-PDB) crystal structure with $1.75 \AA$ resolution has one SO4 371A (sulphate ion) ligandbinding residue (Fig. 6, Table 2). Figure 6 reveals the top five NP 2GIB-ACE2 docking versions. 
RNA binding domain crystal structure SARSCoV-2 NP (2OFZ-PDB) with X-diffraction resolution $1.17 \AA$ A has one Edo 638 (1, 2-Ethanediol) ligand-binding residue (Fig. 7, Table 2). Figu- re 8 reveals the top five NP 2OFZ-ACE2 docking versions.

The RMSD is the most common quantitative measure of the correlation between two atomic

\section{Table 1}

Predication of ion ligand site residues of NP CoVs and ACE2

\begin{tabular}{|c|c|c|}
\hline Source & \begin{tabular}{c|} 
Ion \\
ligand
\end{tabular} & Pos. \\
\hline \multirow{5}{*}{ SARS-CoV-2 } & ZN & $\begin{array}{c}\text { D3,P20,D22,H59, D82,E118, H145, E174, Q260, N285, E290, R293, D297, } \\
\text { H300, R319, H356, Y360, D415 }\end{array}$ \\
\hline & $\mathrm{CU}$ & T76, D82, Q83, G85, Y86, R92, Y111, Y112 \\
\hline & $\mathbf{C A}$ & R92, Y111, Y112, T115, G116, P117, N228 \\
\hline & NA & P73, F274, W330, F346, K347 \\
\hline & K & L353, H356 \\
\hline $20 F Z$ & $\begin{array}{l}\text { ZN } \\
\text { FE } \\
\text { MG } \\
\text { MN } \\
\text { NA }\end{array}$ & $\begin{array}{c}\text { S2, F4, H10, D33, R44, Y60, Y62, E69, H96 } \\
\text { Y38, Y62, R100 } \\
\text { G50, K51 } \\
\text { A6, T8, A41, R43, R58, Y60 } \\
\text { P24 }\end{array}$ \\
\hline \multirow[t]{3}{*}{ ACE2 (1R42) } & $\mathbf{Z N}$ & $\begin{array}{c}\text { Q6,E39,C11,D118,N119,P120,C123,Y178,D183,H221,H223,Y237,C243,H247,D } \\
\text { 251,R255,N320,K323, C326,H327,P328,D332,D337,C343,D350,H356,H360,H38 } \\
\text { 3,E384,E388,H399,E461,H475,E477,Y479,D481, H487,Y497,H517,L521,H522, } \\
\text { C524,D525,E546,E553,N560,K582,S593, D597 }\end{array}$ \\
\hline & MG & H356, H360 \\
\hline & NA & D332, D337. K447, K523, D525, G587 \\
\hline
\end{tabular}
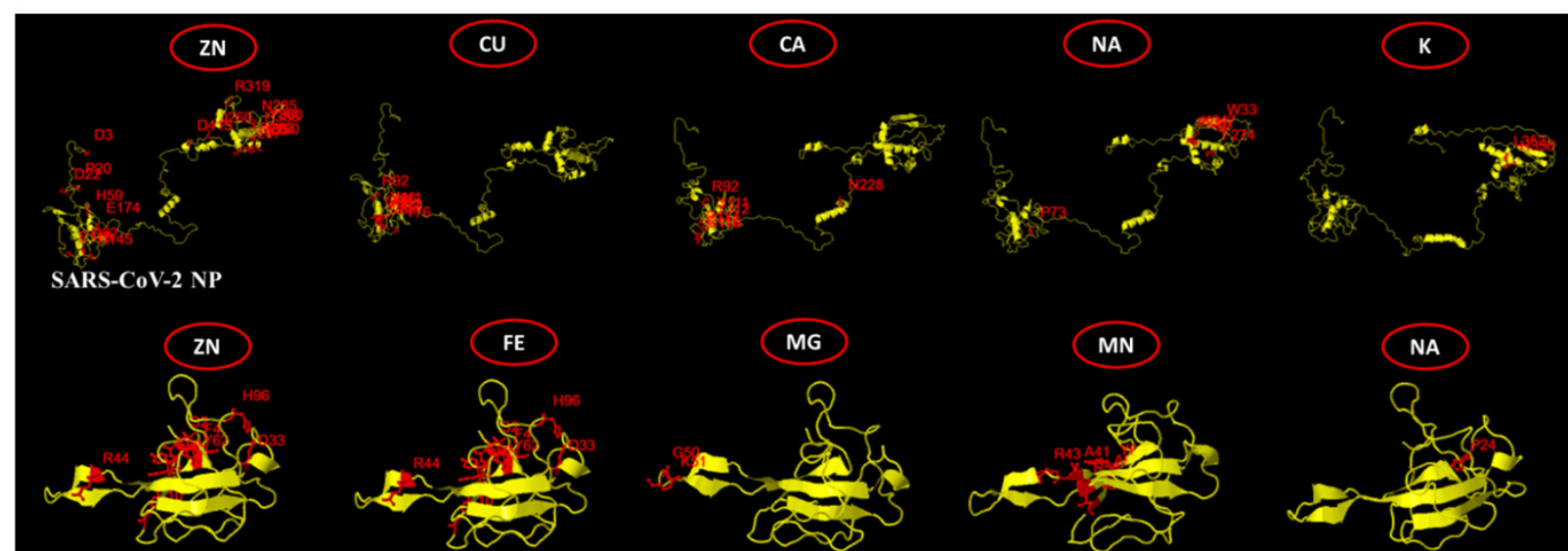

2OFZ
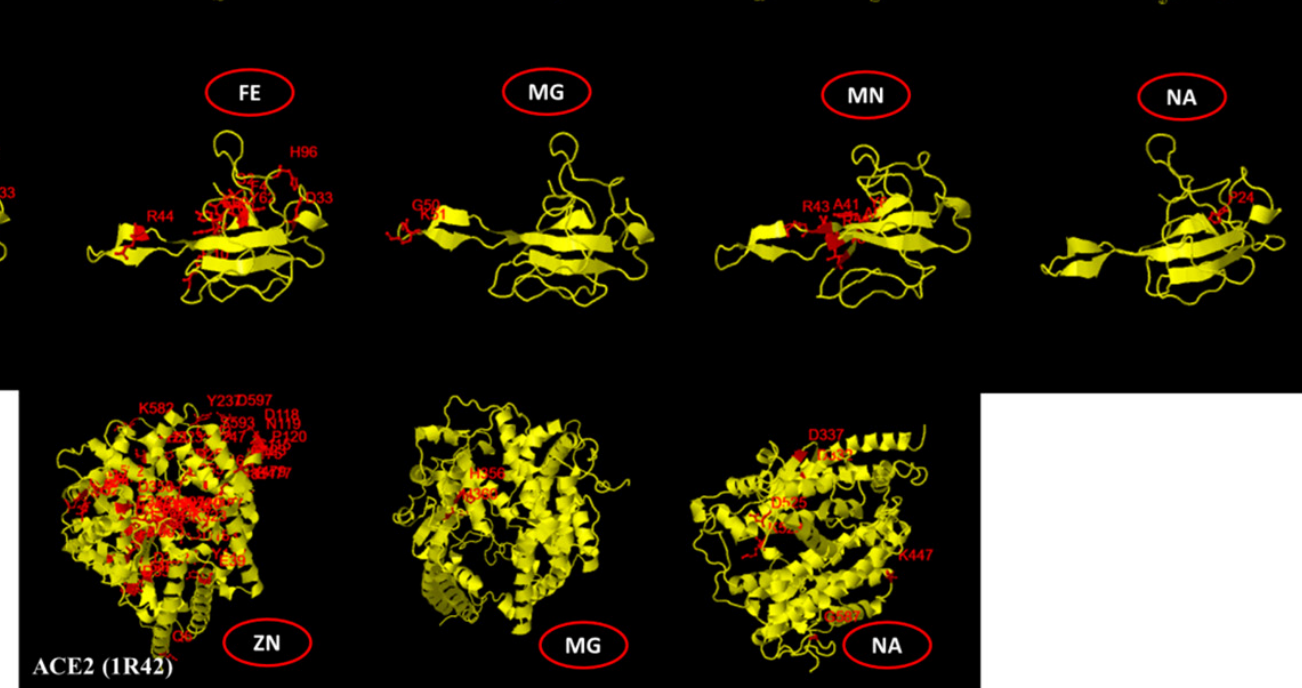

F i g. 2. Ion binding sites residues. SARS-CoV-2 NP (QJR91601.1): 2D structure and ion ligands ( $\mathrm{Zn}, \mathrm{Cu}, \mathrm{Ca}, \mathrm{Na}, \mathrm{K}) .2 \mathrm{FZ}$ : Crystal structure of NP, RNA binding domain and ion ligands ( $\mathrm{Zn}, \mathrm{Fe}, \mathrm{Mg}, \mathrm{Mn}$, and $\mathrm{Na}$ ), and $A C E 2$ : Crystal structure of angiotensin-converting enzyme II and ion ligands $(\mathrm{Zn}, \mathrm{Mg}$, and $\mathrm{Na})$ 
co-ordinates superposed. The RMSD values are displayed and computed in $\AA$. Table 3 shows the docking scores and ligand RMSD for the five patterns. Moreover, without expected ligand binding sites in PDB, we isolated four NP domains of SARS-CoVs. These domains are the N-terminal RNA binding domain NP SARS-CoV (6M3M), the SARS-CoV-2 (6YUN) C-terminal dimerization domain, the SARSCoV (2CJR) oligomerization domain, and the SARS-CoV (1ssk) N-terminal RNA binding domain.
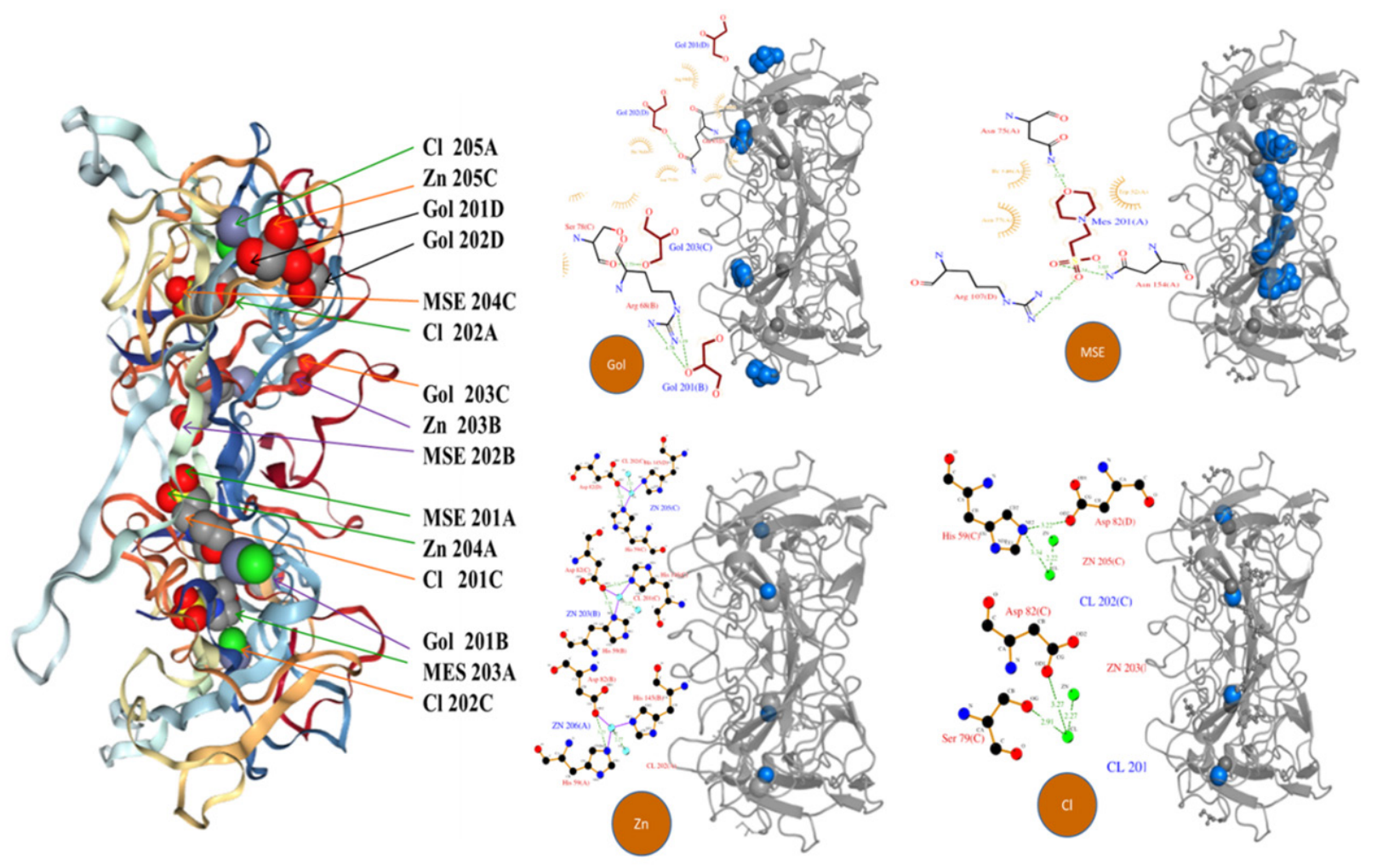

F i g. 3. Crystal structure of NP SARS-CoV-2 RNA binding domain (6VYO). Left figure shows all ligand binding sites. Gol: Glycerol binding sites, chemical structures and the loci on NP. MSE:

2-(N-Morpholino-Ethanesulfonic acid) binding sites and there loci on NP. Zn: Zinc ion metal binding sites and there loci on NP. $\mathrm{Cl}$ : Chloride ion metal binding sites and there loci on NP.

Table 2

Ligand sites residues of NP SARS-CoVs and ACE2. Green highlight: ligands group on 6VYO. Pink highlight: ion metal ligands group of ACE2. Orange highlight unknown ligands group on ACE2

\begin{tabular}{|c|c|c|c|c|c|c|c|}
\hline \multicolumn{2}{|c|}{ NP SARS-CoV-2 (6VYO) } & \multicolumn{2}{|c|}{ NP SARS-CoV (2GIB) } & \multicolumn{2}{|c|}{ NP SARS-CoV (20FZ) } & \multicolumn{2}{|c|}{ ACE2 (1R42) } \\
\hline Lig. & Pos. & Lig. & Pos. & Lig. & Pos. & Lig. & Pos. \\
\hline $\begin{array}{l}\text { MSE 201A } \\
\text { MSE 203A }\end{array}$ & $\begin{array}{l}\text { Asn } 75 \\
\text { Asn } 154\end{array}$ & S04 371A & Arg 277 & EDO 638A & Ser 106 & NAG $800 \mathrm{~A}$ & $\begin{array}{l}\text { Asn } 90 \\
\text { Lys } 26\end{array}$ \\
\hline MSE 202A & $\operatorname{Trp} 52$ & & & & & NAG $801 \mathrm{~A}$ & Gln 81 \\
\hline MSE $024 \mathrm{C}$ & Arg 107 & & & & & NAG 802A & Phe 308 \\
\hline Gol 201B & $\operatorname{Arg} 68$ & & & & & Cl 803A & Arg 169 \\
\hline Gol 203C & Ser 78 & & & & & Zn 804A & Glu 402 \\
\hline Gol 201D & Trp 132 & & & & & & His 374 \\
\hline Gol 202D & $G \ln 83$ & & & & & & His 378 \\
\hline Zn 206A & His 59 & & & & & Unk 901B & Asp 615 \\
\hline $\mathrm{Zn} 203 \mathrm{~B}$ & Asp 82 & & & & & Unk 902B & Tyr 613 \\
\hline $\mathrm{Zn} 205 \mathrm{C}$ & His 59 & & & & & Unk 903B & $=$ \\
\hline $\mathrm{Cl} 202 \mathrm{~A}$ & His 145 & & & & & Unk 904B & $=$ \\
\hline $\mathrm{Cl} 201 \mathrm{C}$ & Ser 79 & & & & & Unk 905B & $=$ \\
\hline $\mathrm{Cl} 202 \mathrm{C}$ & Zn 59 & & & & & Unk 906B & $=$ \\
\hline
\end{tabular}




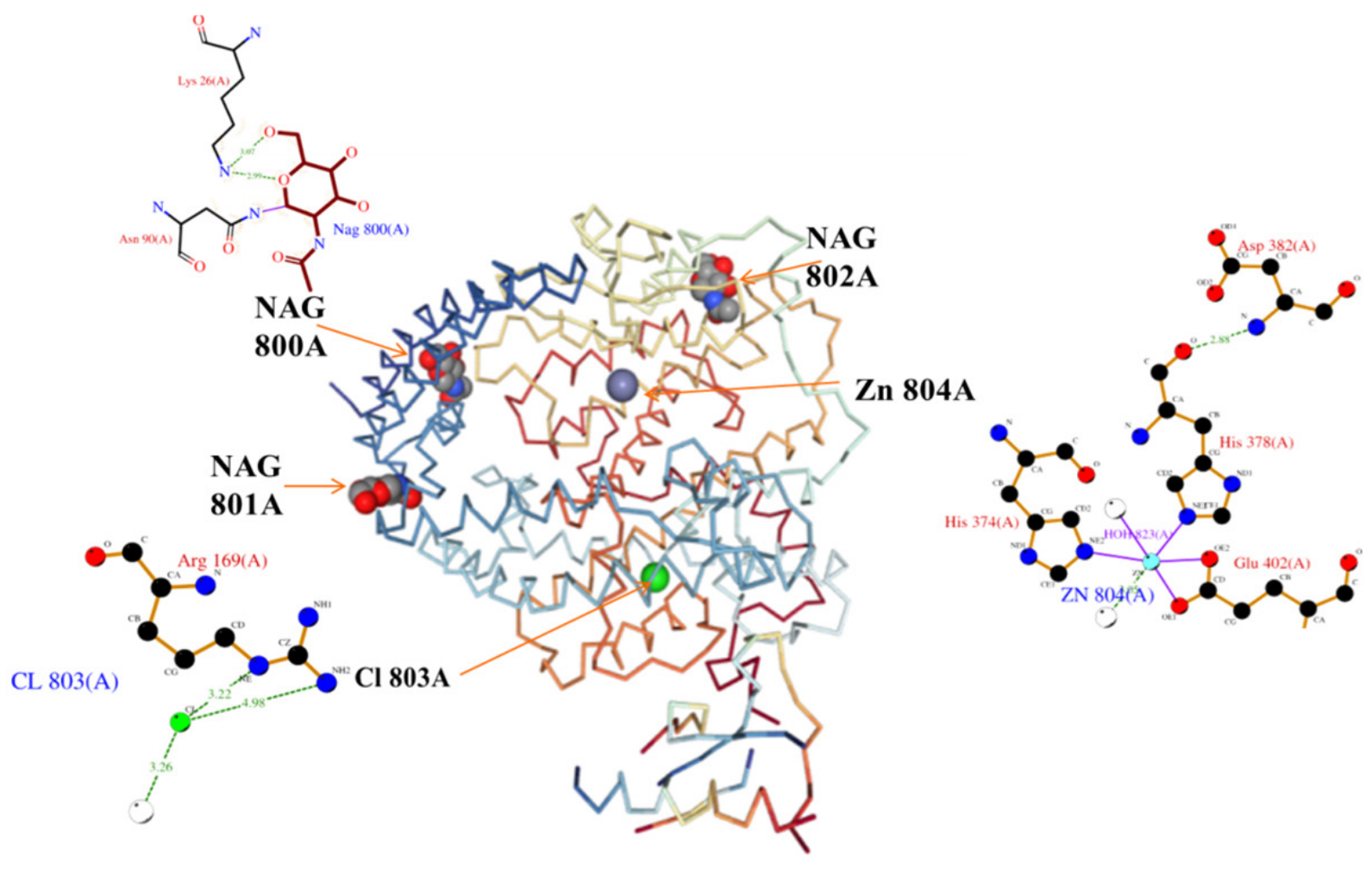

F i g. 4. Crystal structure of ACE2 shows ligand binding sites residues. NAG:

N-Acetyl-D-Glucosamine chemical structure and there loci on ACE2. ZN: Zinc ion m chemical structure and its locus on ACE2. Cl: Chloride ion metal chemical structure and its locus on ACE2.

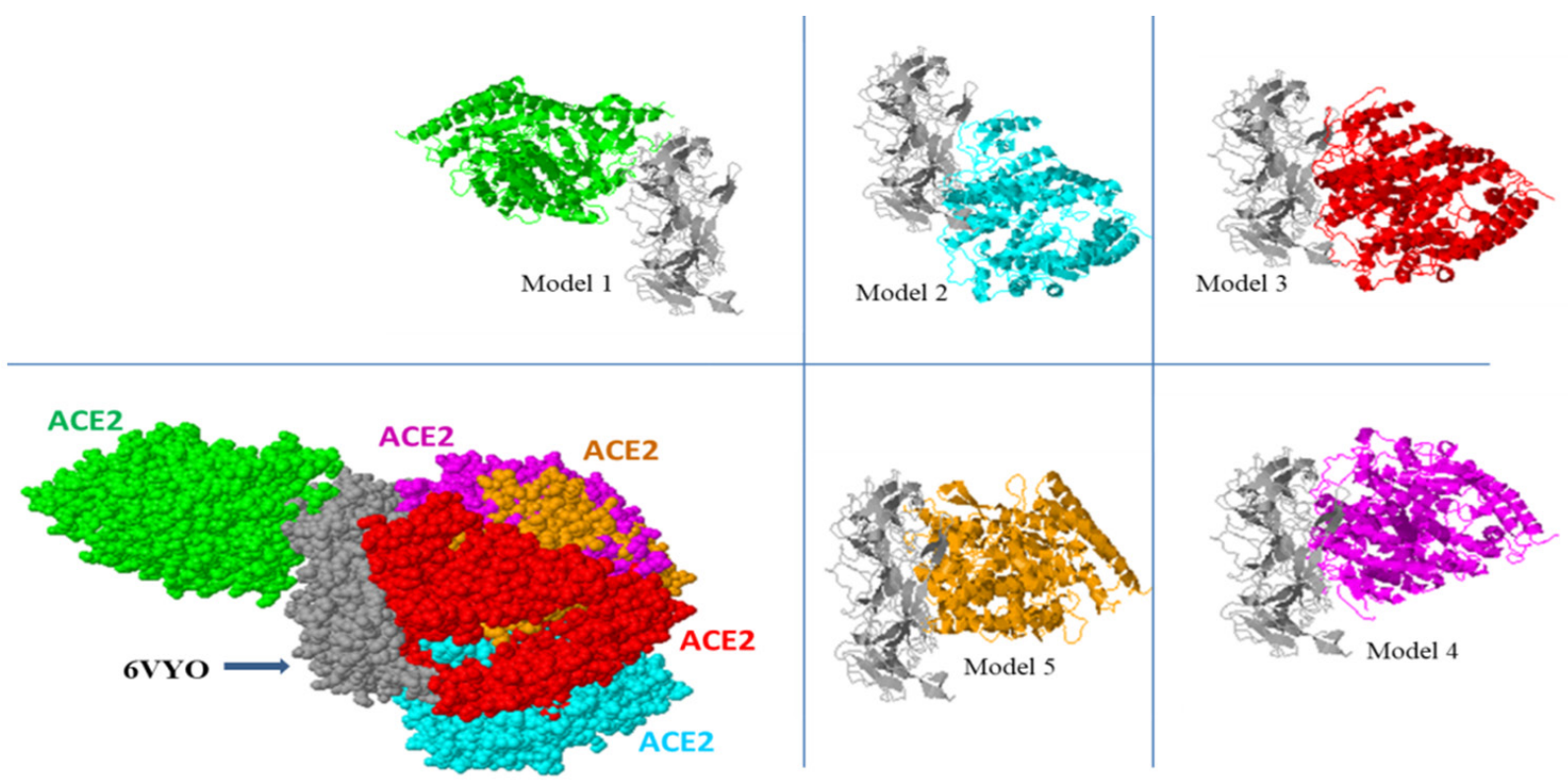

F i g. 5. Five homology models of crystal structure docking NP 6VYO-ACE2. Spacefill architecture of all docking models.

Table 3

Docking scores and RMSD of the top five models of NP-ACE2 interaction

\begin{tabular}{|l|c|c|c|c|c|c|}
\hline Top & SARS-CoV-2 & 6VYO-ACE2 & SARS-CoV-2 & 2OFZ-ACE2 & SARS-CoV & 2GIB-ACE2 \\
\hline Models & Dock score & RMSD $(\AA)$ & Dock score & RMSD $(\AA)$ & Dock score & RMSD $(\AA)$ \\
\hline 1 & -268.42 & 58.23 & -258.20 & 98.61 & -223.67 & 59.28 \\
\hline 2 & -253.57 & 54.54 & -240.06 & 94.71 & -221.21 & 82.03 \\
\hline 3 & -251.23 & 71.12 & -233.58 & 95.99 & -219.93 & 86.82 \\
\hline 4 & -242.47 & 51.09 & -225.63 & 93.11 & -211.12 & 89.87 \\
\hline 5 & -237.55 & 64.06 & -224.48 & 93.22 & -208.02 & 62.13 \\
\hline
\end{tabular}




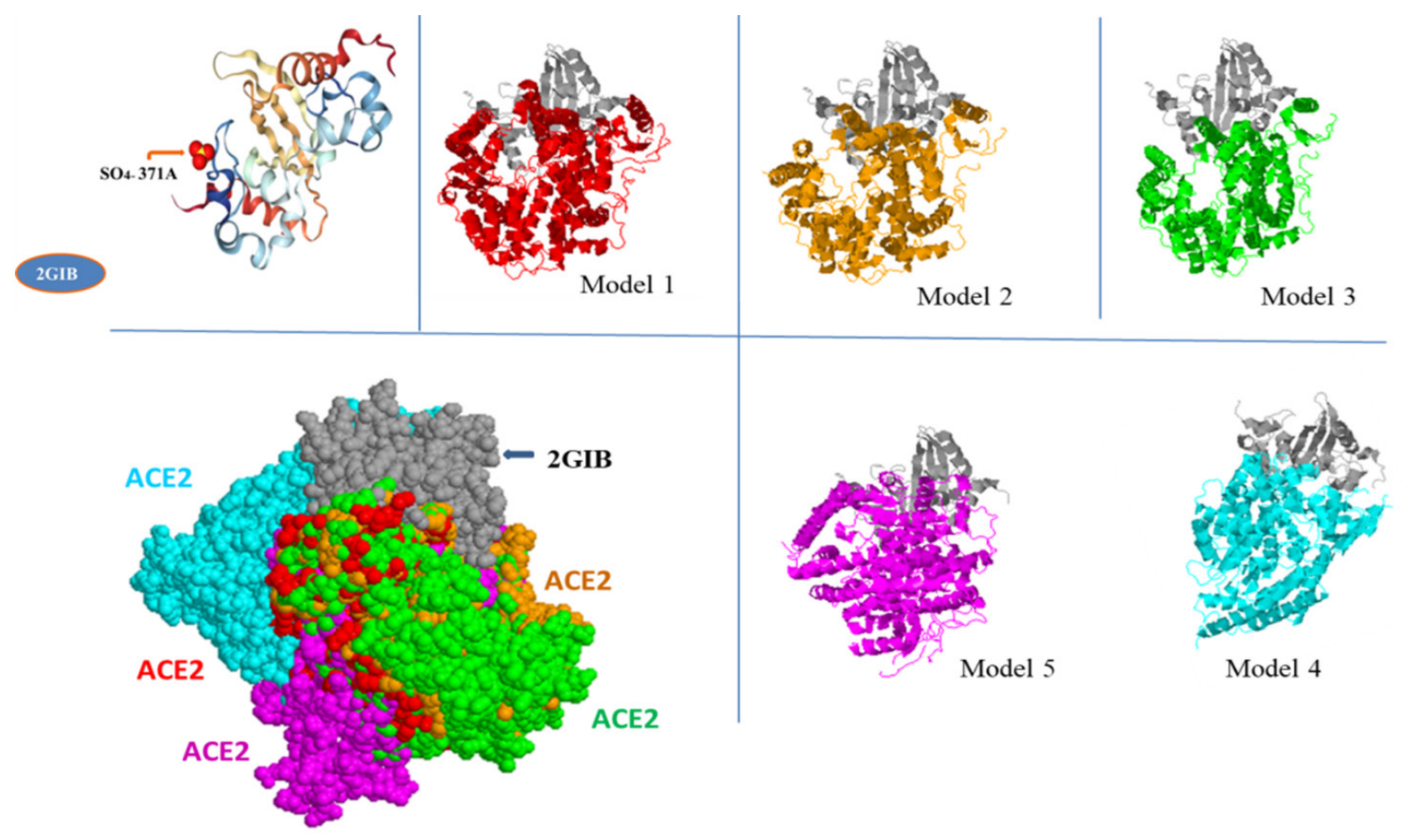

F i g. 6. Top left: Crystal structure of NP 2GIB with ligand SO4. Top five docking models of NP 2GIB-ACE2. Down left: Spacefill architecture of all docking models.

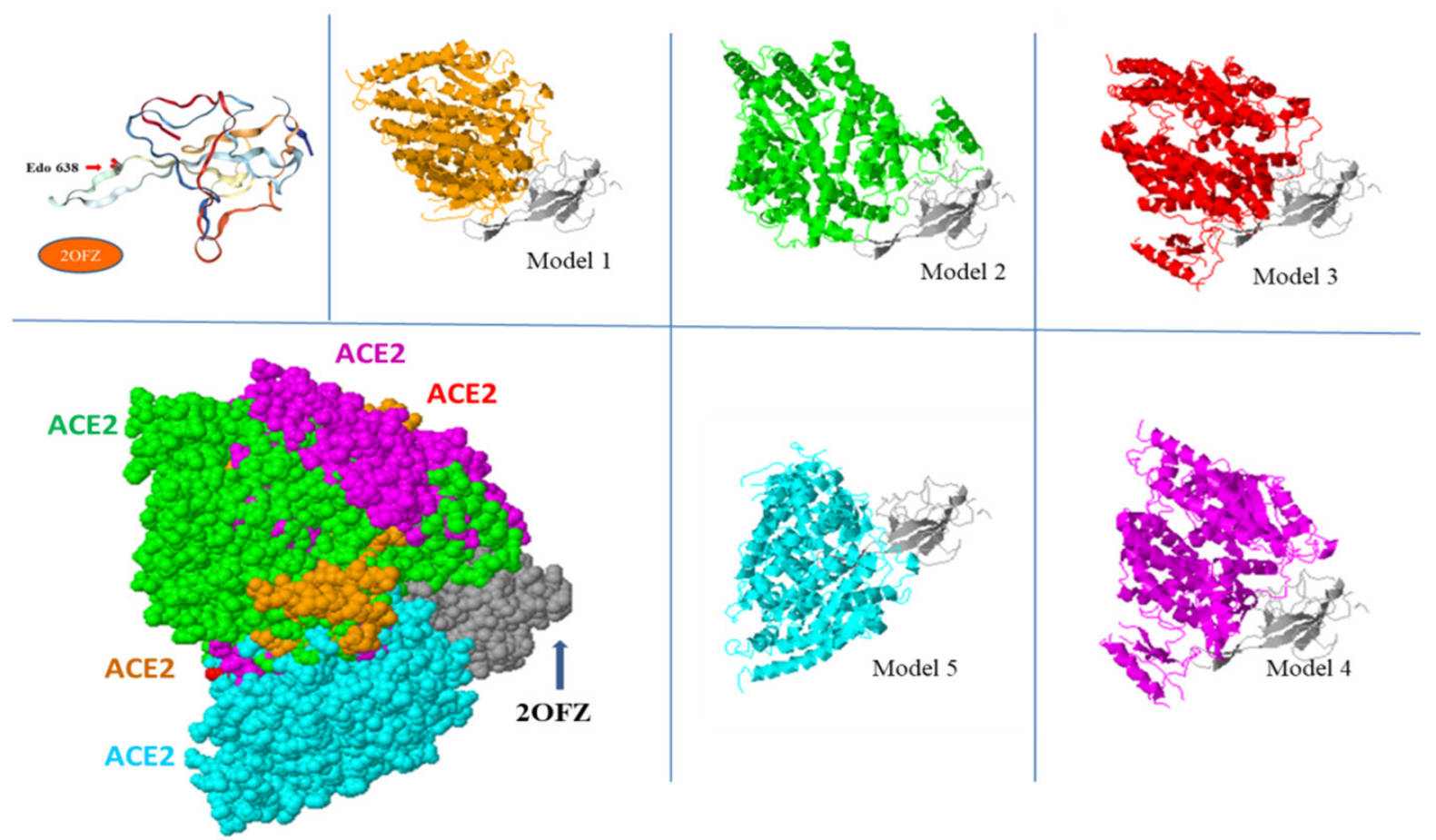

F i g. 7. Top left: Crystal structure of NP 2OFZ with ligand Edo. Top five docking models of NP 2OFZ-ACE2. Down left: Spacefill architecture of all docking models.

Discussion. So far it has been confirmed that instead of human SARS-CoV or MERS-CoV, SARS-CoV-2 will quickly transfer and inflict less intense human infection. Different cases have led to SARS-CoV-2 rapid spread to the extent of the outbreak, including high morbidity and mortality, expansion of health facilities in the countries most impacted, absence of vaccine stocks, absence of approved medicines [17, 18].

The NPs of coronaviruses contain a high proportion of serine residues with many sites of phosphorylation. The NP after the infection was 
phosphorylated [19]. NP phosphorylation in the infected cells and transfected eukaryote cells was also shown inside the $\mathrm{N}$ gene [20].

Interestingly, with $>88$ percent identity, the sequence comparison between SARS-CoV-2 NP and related SARS-CoVs, the residues present in the receptor-interacting motive is strongly maintained, sharing twenty residues of all coronavirus patterns of NPs.

It is understood now that SARS-CoV-2 uses ACE2 receptors to infect lung alveolar epithelial cells [21]. Roughly $17 \%$ of protein-protein crosssectional tests were of poor retained resemblance between the NP sequences and the ACE2 receptor. During identity declines, 21 strongly retained sites in the grey line between NPs and ACE2 (Fig. 1). This might boost linking locations [22].

We also introduced intelligent consensus simulation methods to forecast the 2D structure of NP CoVs for further refining of the predictions obtained from the individual models. Modelling of consensus aims to enhance the display of the model's evaluation and thereby reduces test errors. In the current analysis we did not only predict the 2D structure of the NPs but also predict the residues in the amino acid sequences under review for ionic binding sites. There are 40 ion residues and 21 residues for $2 \mathrm{OFZ}$ in the full sequence of SARS-CoV-2 NP, while ACE2 has 57 ion residues. With the interaction between SARS-CoV-2 NP and ACE2, the most predicted ions were $\mathrm{Zn}$, and this could be significant.

Molecular docking assists in recognizing the optimized conformation between the imaging agent and its receptor of the protein complexes. It provides evidence of the orientation of imaging variables in the receptor-binding area. The key objective is to consider the molecular interactions that take place during binding and compare these results with the study of PROCHECK [23]. In the current work, five NP 6VYO-ACE2 correctly docking models have been observed according to their Figure 5 ligand binding sites. The docking study found that various kinds of bonding interactions and hydrogen-bonding interactions were prevalent.

Locus (Asp 82, His 59 His 145) of 6VYO and (Arg 169, Glu 402, His 374, His 378) of ACE2 are the primary contacting residues. Another highenergy docking was reported in 6VYO and ACE2 loci (Asp 82, His 59 His 145) (Asp 615 Tyr 613, and unknown ligand residues Unk 901B, 902B, 903B, 904B, 905B, and 906B) (Table 2). Previous studies have reported that the two main residues
(479 and 487) in the SARS-CoV spike protein are associated with human ACE2 receptor recognition [24], while the residues corresponding to N479, Q493, and T487 are associated with N501 in the SARS-CoV-2 S protein. These residue changes are energetically beneficial changes to the receptor interaction $[25,26]$. There has also been shown positive interactions with a Spike glycoproteinACE2 complex of $-6.8 \mathrm{kcal} / \mathrm{mol}$ binding affinity. This association constitutes an essential number of amino acids with which van der Waals associate [27].

The preceding outcome is in accordance with our knowledge. Since it has only one ligandbinding site for both the NP dimerization domain (2GIB) and the binding domain (2OFZ). Five favoured docking models, 2GIB-ACE2 and 2OFZ-ACE2, were registered with the results. In Figures 6 and 7, respectively, the descriptions of the descriptors, their contribution, and frequency of appearance in all five versions are explained in detail. The research on the other hand noted that inhibiting SARS-CoV-2-associated AbI kinase could block the ACE2 receptor [28]. Major structural disruptions in the target proteins can potentially cause changes in thermodynamic stability at earlier docking stages [29]. Analysis showed that phenol derivative and anti-HIV drugs would aid the discovery of COVID-19 drugs by interfering with docking systems [30]. The binding of five molecules to RBD-SARS-CoV-2-ACE2 resulted in binding affinities ranging from (-4.2 to $-6.9 \mathrm{kcal} / \mathrm{mol}$ ) in other tests. ACE2's hydrophobic pocket infiltrates the unique phenylalanine in the loop (F486), thereby playing a significant role in the acknowledgment [31-33].

Ligand binding sites for NP domains of SARSCoV (6M3M), SARS-CoV-2 (6YUN), SARS-CoV (2CJR), and SARS-CoV (1ssk) were not identified by using in silico analysis methods.

It is understood that a docking score lower than -10 typically reflects strong binding interactions that are mainly hydrophobic. The root means a protein's square RMSD deviation in X-ray diffraction resolution is normally 2-3.5 $\AA$. The RMSD within this range is regarded as good, according to the template. Our data scored a lower docking score and RMSD between protein docking interaction of approximately -250 and 50 $\AA$ respectively. Our analysis has shown that the results of X-ray diffraction data processing still differ from the use of the methods of bioinformatics and mathematical calculations even though using identical server forms. 
Conclusions. Several reports show that blocking the ACE2 receptor in the treatment of SARS-CoV-2 will be an advantageous approach. This research, therefore, aims to investigate new data processing to compare chemical structures with their biological behaviour, as well as ligand-binding affinity, at the level of atoms between the NP and the ACE2 receptor. The research highlights and correlation characteristics are largely responsible for the viral $\mathrm{NP}$ and ACE2 receptor that can be further changed for improved binding and selectivity.

The basic two-dimensional (2D) structure appearing in all the models includes the prediction of ion ligand binding sites to be easier to compute. This knowledge will also help to escape the binding of viral proteins to the associated receptors on the host cell in future development.

Data research cannot show the exact practical value of protein-protein docking. However, identification of molecular docks will in our overview lead to autoassociated proteins and serve as a regulatory transition to locate the protein. It may also be a required step for viral entry and assembly.

Acknowledgments. The authors are very thankful for the increase in the standard of this work by the University of Mosul, College of Medicine.

Competing Interests. The authors have confirmed that there are no conflicting interests.

Funding. No particular grant from any agency was awarded to this article.

\section{МОЛЕКУЛЯРНИЙ ДОКІНГ БІЛКА НУКЛЕОКАПСИДУ SARS-COV-2 3 АНГІОТЕНЗИН-ПЕРЕТВОРЮЮ- ЧИМ ФЕРМЕНТОМ II}

\author{
Алі А. Давуд, Махмуд А.А. Аль-Тобджі', \\ Зіяд Т. Аль-Ррассам ${ }^{3}$ \\ ${ }^{1}$ Кафедра анатомії, медичний коледж, \\ Університет Мосула, Мосул, Ірак \\ 2 Департамент біології, науковий коледж, \\ Університет Мосула, Мосул, Ірак \\ 'Департамент біофізики, науковий коледж, \\ Університет Мосула, Мосул, Ірак

\section{Резюме}

Спалахи захворювання COVID-19, викликаного коронавірусом SARS-CoV-2, свідками яких $\epsilon$ сучасний світ, залишаються небезпечними для життя людей. Мета. Ключовою метою цього дослідження було використання методу біоінформатики для прогнозування молекулярного докінгу, асоційованого з ACE2 нуклеокапсидного білка SARS-Co-V. Методи. У цьому дослідженні були використані різні інструменти біоінформатики для порівняння хімічних структур з їх біологічною поведінкою на рівнях атомів та спорідненості до ліганду. Це дослідження було спрямоване на вивчення нового способу аналізу даних. Результати. Розрахована базова 2D-структура, яка зустрічається у всіх моделях, що вимагає прогнозування сайтів зв'язування іонних лігандів. Основні моменти аналізу та пов'язані з ним характеристики значною мірою відповідають за білок нуклеокапсиду вірусу та рецептор ACE2, які можуть бути додатково змінені для поліпшення зв'язування та селективності. Висновки. Точне функціональне значення білок-білкового докінгу неможливо встановити. Але виявлений молекулярний докінг може мати допоміжну функцію у самозв'язуванні білків, слугуючи регуляторним перемикачем для локалізації білка.

Ключові слова: COVID-19, SARS-CoV-2, ангіотензин-перетворюючий фермент II (ACE2), нуклеокапсид, молекулярний докінг, рецепторзв'язуючий білок (RBD), RMSD.

1. Chen Y, Liu Q, Guo D. Emerging coronaviruses: Genome structure, replication, and pathogenesis. J Med Virol. 2020; 92:418-423. https://doi. org/10.1002/jmv.25681. PMC7167049

2. Gralinski LE, Menachery D. Return of the Coronavirus: 2019-nCoV. Viruses. 2020; 12:135. https://doi.org/10.3390/v12020135. PMC7077245

3. Liu W, Morse S, Lalonde T, Xu S. Learning from the Past: Possible Urgent Prevention and Treatment Options for Severe Acute Respiratory Infections Caused by 2019-nCoV. Chembiochem. 2020; 21:730-738. https://doi.org/10.1002/ cbic.202000047. PMC7162020

4. Dawood A. Mutated COVID-19, May Foretells Mankind in a Great Risk in The Future. N Mic N Inf. 2020. https://doi.org/10.1016/j. nmni.2020.100673

5. McBride R, Zyl M, Fielding C. The coronavirus nucleocapsid is a multifunctional protein. Vi- 
ruses. 2014; 6:2991-3018. http://doi: 10.3390/ v6082991.

6. Wurm T, Chen H, Hodgson T, Britton P, Brooks G, Hiscox G.A. Localization to the nucleolus is a common feature of coronavirus nucleoproteins, and the protein may disrupt host cell division. J Virol. 2001; 75:9345-9356. https:// doi.org/10.1128/JVI.75.19.9345-9356.2001. PMC114503

7. You J, Dove K, Enjuanes L, DeDiego L, Alvarez E, Howell J, et al. Subcellular localization of the severe acute respiratory syndrome coronavirus nucleocapsid protein. J Gen Virol. 2005; 86 Pt 12, 3303-3310. https://doi.org/10.1099/ vir.0.81076-0.

8. Song W, Gui M, Wang X, Xiang Y. Cryo-EM structure of the SARS coronavirus spike glycoprotein in complex with its host cell receptor ACE2. PLoS Pathog. 2018; 14, e1007236. https://doi.org/10.1371/journal.ppat.1007236. PMC6107290

9. Lan J, Ge J, Yu J, Shan S, Zhou H, Fan S, et al. Structure of the SARS-CoV-2 spike receptor-binding domain bound to the ACE2 receptor. Nature. 2020; 581:215-220. https://doi. org/10.1038/s41586-020-2180-5

10. He J, Tao H, Yan Y, Huang S-Y, Xiao Y. Molecular Mechanism of Evolution and Human Infection with SARS-CoV-2. Viruses. 202; 12:428. https://doi.org/10.3390/v12040428.

11. Lu R, Zhao X, Li J, Niu P, Yang B, Wu H, et al. Genomic characterization and epidemiology of 2019 novel coronavirus: implications for virus origins and receptor binding. Lancet. 2020; 395:565-574. https://doi.org/10.1016/S01406736(20)30251-8

12. Gui M, Song W, Zhou H, Xu J, Chen S, Xiang Y, et al. Cryo-electron microscopy structures of the SARS-CoV spike glycoprotein reveal a prerequisite conformational state for receptor binding. Cell Res. 2017; 27:119-129. https://doi.org/ doi:10.1038/cr.2016.152.

13. Dawood A. Identification of CTL and B-cell epitopes in the Nucleocapsid Phosphoprotein of COVID-19 using Immunoinformatics. Mic J. 2021; 83(1):1-9. https://doi.org/10.15407/microbiolj83.01.078.
14. Pierce BG, Wiehe K, Hwang H, Kim B-H, Vreven T, Weng Z. ZDOCK server: interactive docking prediction of protein-protein complexes and symmetric multimers. Bioinformatics. 2014; 30:1771-3. https://doi.org/10.1093/bioinformat$\mathrm{ics} / \mathrm{btu} 097$. PMC4058926

15. Wan Y, Shang J, Graham R, Baric RS, Li L. Receptor recognition by a novel coronavirus from Wuhan: An analysis based on decade-long structural studies of SARS. J Virol. 2020; 94:(7) e00127-20. https://doi.org/10.1128/JVI.0012720.

16. Dawood A, Altobje M. Inhibition of N-linked Glycosylation by Tunicamycin May Contribute to The Treatment of SARS-CoV-2. Microbiol Path. 2020; 149:104586. https://doi.org/10.1016/j.micpath.2020.104586.

17. Walls C, Park J, Tortorici A, Wall A, McGuire T, Veesler D. Structure, Function, and Antigenicity of the SARS-CoV-2 Spike Glycoprotein. Cell. 2020; 181(2):281-292. https://doi.org/10.1016/j. cell.2020.02.058.

18. Dharma K, Sharun K, Tiwari R, Dadar M, Malik S, Singh P, Chaicumpa W. COVID-19, an emerging coronavirus infection: advances and prospects in designing and developing vaccines, immunotherapeutics, and therapeutics. Hum Vaccin Immunother. 2020:1-7. https://doi.org/10.10 80/21645515.2020.1735227.

19. Chen Y, Guo Y, Pan Y, Zhao ZJ. Structure analysis of the receptor binding of 2019-nCoV. Biochem Biophys Res Commun. 2020; 17: S0006291X (20) 30339-9. https://doi.org/10.1016/j. bbrc.2020.02.071.

20. Lin L, Shao J, Sun M, Liu J, Xu G, Zhang X, et al. Identification of phosphorylation sites in the nucleocapsid protein (N protein) of SARS-coronavirus. Int J Mass Spect. 2007; 268:296-303. https://doi.org/10.1016/j.ijms.2007.05. 009.

21. Dawood A, Alnori H. Tunicamycin Anticancer Drug May Reliable to Treat Coronavirus Disease-19. OAMJMS. 2020; 8(T1):129-133. https://doi.org/10.3889/oamjms.2020.4954

22. Velavan P, Meyer G. The COVID-19 epidemic. Trop Med Int Health. 2020; 25(3): 278-280. https://doi.org/10.1111/tmi.13383. PMC7169770 
23. Hasan A, Hossain M, Alam J. A computational assay to design an epitope-based Peptide vaccine against Saint Louis encephalitis virus. Bioinformatics and Biology insights. 2013; 7: BBI-S13402. http://doi.org/10.4137/BBI.S13402.

24. Thomas J, Maria O, Serrano L, Pujo H, Rangel R. Role of changes in SARS-COV-2 spike protein in the interaction with the human ACE2 receptor: An in silico analysis. EXCLI J. 2020; 19:410417. http://doi.org/10.17179/excli2020-1167.

25. Lu G, Wang Q Gao GF. Bat-to-human: spike features determining 'host jump' of coronaviruses SARS-CoV, MERS-CoV, and beyond. Trends Microbiol. 2015; 23: 468-78. https://doi. org/10.1016/j.tim.2015.06.003. PMC7125587

26. Luan J, Lu Y, Jin X, Zhang L. Spike protein recognition of mammalian ACE2 predicts the host range and an optimized ACE2 for SARSCoV-2 infection. Biochem Biophys Res Comm. 2020; 526(1):165-9. https://doi.org/10.1016/j. bbrc.2020.03.047.

27. Ibrahim IM, Abdelmalek DH, Elshahat ME, Elfiky AA. COVID-19 spike-host cell receptor GRP78 binding site prediction. J Infect. 2020; 80(5):554-62. https://doi.org/10.1016/j. jinf.2020.02.026.

28. Narkhede R, Cheke R, Ambhore J, Shinde S. The Molecular Docking Study of Potential Drug Candidates Showing Anti-COVID-19 Activity by Exploring of Therapeutic Targets of SARSCoV-2. EJMO. 2020; 4(3):185-195. https://doi. org/10.14744/ejmo.2020.31503.

29. González-Paz1 L, Lossada C, Moncayo L, Romero F, Paz J, Vera-Villalobos J, et al. Molecular Docking and Molecular Dynamic Study of two Viral Proteins associated with SARS-CoV-2 with Ivermectin. Preprints. https://doi.org/10.20944/ preprints202004.0334.v1.

30. Gomez D, Huber K, Klumpp S. On protein folding in crowded conditions. J Phys Chemis Let. 2019; 10(24):7650-7656. https://doi. org/10.1021/acs.jpclett.9b02642.

31. Peele A, Durthi C, Srihansa T, Krupanidhi S, Sai A, Babu D, et al. Molecular docking and dynamic simulations for antiviral compounds against SARS-CoV-2: A computational study. Inform. Med. Unlo. 2020; 19:100345. https://doi. org/10.1016/j.imu.2020.100345

32. Cubuk H, and Ozbil M. Comparison of Clinically Approved Molecules on SARS-CoV-2 Drug Target Proteins: A Molecular Docking Study. ChemRxiv. 2020. https://doi.org/10.26434/chemrxiv.12090828.v1.

33. Yu R, Chen L, Lan R, Shen R, Li P. Computational screening of antagonists against the SARSCoV-2 (COVID-19) coronavirus by molecular docking. Int J Antmic Ag. 2020; 7:29. https://doi. org/10.1016/j.ijantimicag.2020.106012

Received 3.12.2020 